\title{
Prediction of Osteoporosis through Radiographic Assessment of Proximal Femoral Morphology and Texture in Elderly; is it Valid and Reliable?
}

\author{
Yaşlılarda Proksimal Femur Morfoloji ve Dokusunun Radyografik Değerlendirilmesi \\ Yoluyla Osteoporozun Tahmini, Geçerli ve Güvenilir midir?
}

Özkan Köse, Ömer Faruk Kılıçaslan, Hasan Onur Arık*, Ümit Sarp**, İclal Erdem Toslak***, Mehmet Uçar****

Antalya Education and Research Hospital, Clinic of Orthopedics and Traumatology, Antalya, Turkey

*Yozgat State Hospital, Clinic of Orthopedics and Traumatology, Yozgat, Turkey

**Yozgat State Hospital, Clinic of Physical Medicine and Rehabilitation, Yozgat, Turkey

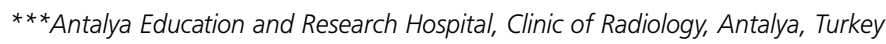

$* * * *$ Bozok University Faculty of Medicine, Department of Physical Medicine and Rehabilitation, Yozgat, Turkey

Summary

Objective: The purpose of this study was to determine the best predictive radiographic measurement method to identify the presence of osteoporosis and test the inter-observer and intra-observer reliability and validity of these methods in postmenopausal women.

Materials and Methods: Ninety-two elderly female patients who presented with hip pain were included. Hip radiographs were used to determine the values of Singh index (SI), canal-to-calcar ratio (CCR), and cortical thickness index (CTI). All measurements were performed by two independent observers on two separate occasions, at least 4 weeks apart. Bone mineral density (BMD) was assessed by DEXA. In the first part of the analysis, reliability of the all measurement methods was tested. In the second part, correlation coefficient (Pearson $r$ ) was used to determine the relationship between the measurement methods and BMD. Finally ROC curve analysis was performed to determine the sensitivity, specificity, and threshold values for each radiographic measurement method.

Results: Intra-observer reliability analysis of SI revealed kappa coefficient of 0.359 for observer A, and 0.224 for observer B. Inter-observer reliability analysis of SI revealed kappa coefficient of 0.070 for observer A and 0.051 for observer B. The intra-observer and inter-observer reliability was good and excellent for CTI and CCR for both observers (ICC: 0.920 and ICC: 0.936). There was no correlation between SI and BMD ( $p=0.818)$. On the other hand, there was a significant correlation between $C T I$ and $C C R$ and BMD ( $p=0.001)$. All measured indices were significantly different $(p<0.05)$ between osteoporotic and non-osteoporotic patients. CTI value less than 0.3 or CCR value less than 0.47 reflects the presence of osteoporosis with $100 \%$ sensitivity and $98 \%$ specificity.

Conclusion: SI is not reliable and do not correlate with BMD. However, both CTI and CCR showed good and excellent reliability, and each index correlated well with the real BMD values. (Türk Osteoporoz Dergisi 2015;21: 46-52)

Key words: Osteoporosis, pelvis radiography, bone mineral density, Singh index, Cortical thickness index, calcar to canal ratio

Conflicts of Interest: The authors reported no conflict of interest related to this article.

\section{Özet}

Amaç: Bu çalışmanın amacı, postmenepozal kadınlarda osteoporoz varlı̆̆ını kalça grafilerinden belirleyecek en iyi radyografik ölçüm metodunu belirlemek ve bu yöntemlerin geçerlilik ve güvenilirliğini araştırmaktır.

Gereç ve Yöntem: Kalça ağrısıyla hastaneye başvuran 92 postmenepozal kadın hasta çalışmaya alındı. Kalça radyografileri değerlendirilerek Singh indeks (Si), kanal kalkar oranı (KKO) ve Kortikal kalınlık indeksi (KKi) ölçüldü. Tüm ölçümler en az 4 hafta arayla iki bağımsız gözlemci tarafından iki kez gerçekleştirildi. Hastaların kemik mineral yoğunluğu (KMY) DEXA ile değerlendirildi. Analizin ilk kısmında tüm ölçüm yöntemlerinin güvenilirliği test edildi. İkinci kısımda KMY ile ölçüm yöntemleri arasındaki ilgileşim analiz edildi, ilgileşim katsayısı (Pearson r) kullanıldı. En sonunda her bir radyografik ölçüm metotlarının sensivite, spesifitesini ve eşik değerini belirlemek için ROC eğri analizi yapıldı. Bulgular: Si'nin gözlemciler içi güvenilirlik analizi gözlemci A için kappa katsayısını 0,359, gözlemci B için 0,224 olarak bulundu. Si, gözlemciler arası güvenilirlik analizi gözlemci $A$ için kappa katsayısını 0,070, gözlemci B için 0,051 olarak bulundu. Gözlemciler içi ve gözlemciler arası

Address for Correspondence/ Yazışma Adresi: Ömer Faruk Kılıçaslan MD, Antalya Education and Research Hospital, Clinic of Orthopedics and Traumatology, Antalya, Turkey Phone: +90 5058441250 E-mail: kilicaslanfaruk@hotmail.com Received/Geliş Tarihi: 10.01.2015 Accepted/Kabul Tarihi: 26.01.2015

Turkish Journal of Osteoporosis, published by Galenos Publishing. / Türk Osteoporoz Dergisi, Galenos Yayınevi tarafindan basılmıştır. 
güvenilirlik KKO ve KKi için iyi ve mükemmeldi (ICC: 0,920 ve ICC: 0,936 ). Si ve KMY ölçümleri arasında ilgileşim bulunamadı ( $p=0,818$ ). Diğer yandan KKO, KKi ve KMY ölçümleri arasında anlamlı bir ilgileşim saptandı $(p=0,001)$. Osteoporotik ve nonosteopotik hastalar arasında ölçülmüş tüm indeksler anlamlı derecede farklıydı $(p<0,05)$. KKi değeri 0,3 den az ve KKO değeri 0,47 den az osteoporoz varlığını \%100 sensivite ve \%98 spesifite ile gösterdiği saptandı.

Sonuç: Si osteoporozu saptamada güvenilir değildir ve KMY ile ilgileşim göstermemektedir. Ancak hem KKO hem de KKI güvenilirdir ve gerçek KMY değerleriyle anlamlı şekilde ilgileşim göstermektedir. (Turkish Journal of Osteoporosis 2015;21: 46-52)

Anahtar kelimeler: Osteoporoz, pelvis radyografisi, kemik mineral yoğunluğu, Singh indeks, Kortikal kalınlık indeksi, kalkar kanal oranı

Çıkar Çatışması: Yazarlar bu makale ile ilgili olarak herhangi bir çıkar çatışması bildirmemiştir.

\section{Introduction}

Osteoporosis (OP) has become a world-wide public health problem as the number of aging populations rise (1). One of the most common complications of osteoporosis is hip fractures due to increased fragility of the bones. Hip fractures can be treated with various surgical treatment methods and implants such as fixed angle plates, dynamic hip screws, proximal femoral nails and prosthetic replacement either hemiarthroplasty or total hip arthroplasty (2-4). During decision making orthopedic surgeons consider several factors to contemplate the best treatment option for a particular patient. In patients who had unstable fracture pattern particularly associated with marked osteoporosis, failure of fixation may occur that results with secondary operations. Several studies have shown that osteoporosis is a major risk factor for failure of fixation in these patients (5). Therefore orthopedic surgeons dealing with treatment of hip fractures in elderly should asses the presence of osteoporosis. In other words preoperative identification and quantification of osteoporosis is useful information for surgeons to contemplate a proper treatment method $(6,7)$.

Currently, bone densitometry has been accepted as the gold standard to assess and quantify the severity of osteoporosis (8). Diagnosis and follow-up of patients with OP should be done with bone densitometry. However, additional cost of the examination and difficulties in obtaining bone densitometry in a patient with hip fracture is the major disadvantages of this examination. Furthermore, bone densitometry equipment may not be readily available in many healthcare centers. On the other hand, direct radiographic examination is always obtained in a patient with hip fracture and it can be utilized to predict the severity of osteoporosis in these patients (9). Although radiographic examination cannot be used as a single method to diagnose the osteoporosis and monitor the treatment, it may provide valuable information for the physicians. Singh index (SI) is one of the traditional techniques used to determine the extent of osteoporosis which is based on radiological appearance of the trabecular bone structure of the proximal femur on a plain antero-posterior hip x-ray (10). These patterns categorized into six different scales or grades corresponding to the degree of bone loss starting from grade 6 , in which all major trabecular systems are visible (normal), to grade 1 in which only the primary compressive trabeculae can be seen (severe osteoporosis).

Other than SI, Dorr et al. described two other indices, namely cortical thickness index $(\mathrm{CTI})$ and calcar to canal ratio (CCR), which define the proximal femoral morphology. Although, these indices were originally developed to select the proper prosthesis design (cemented versus cementless femoral stem) in patients undergoing hip arthroplasty, they reflect the morphological changes associated with osteoporosis (11-13). In relevant literature, there are controversial findings whether these methods can predict the degree of osteoporosis. Moreover, reliability and validity of these methods has not been comprehensively studied. The purpose of this study is twofold, first we aimed to determine the best predictive measurement method on radiographs to identify the presence of osteoporosis and test the inter-observer and intra-observer reliability and validity of these methods in postmenopausal women.

\section{Materials and Methods}

Patients over 60 years of age who were admitted to our outpatient orthopedic clinic with hip pain were included in this prospective study. This study was carried out in accordance with the ethical standards laid down in the 1964 Declaration of Helsinki and its later amendments. All patients gave informed consent prior to their inclusion in the study and institutional review board (Bozok University Faculty of Medicine) approved the study protocol. Patients with previous hip surgery, congenital deformity of the proximal femur, patients with metabolic bone disease, such as Paget's disease, were excluded from the study. All patients underwent direct radiographic examination and bone mineral density (BMD) measurement of the affected hip within the same week. Antero-posterior hip radiographs had been taken with the x-ray beam directed toward the femoral head while the patient is supine with the foot internally rotated $15^{\circ}$ to obtain best views of the femoral neck. X-ray tube was positioned $100 \mathrm{~cm}$ from focal plane of film cassette to yield an image at $20 \%$ magnification. All radiographs were taken with the same digital $x$-ray machine (Silhouette VR x-ray System, GE Healthcare, USA) at $70 \mathrm{kVp}$ and $25 \mathrm{mAs}$. Bone mineral density was measured by DXA of the same femoral neck (Explorer QDR series, Hologic Inc, USA). A T-score of -2.5 or lower was defined as osteoporosis in accordance with World Health Organization. All referred patients filled a questionnaire to obtain demographic information and duration of menopause. Body weight of the subjects was measured with a digital scale and recorded in kilograms, and height of the patients were measured during standing in front of a wall height scale and recorded in meters. Body mass index (BMI) was calculated using standard formula 
(body mass divided by square of the height) and recorded in units of $\mathrm{kg} / \mathrm{m}^{2}$

Two consultant orthopedic surgeons took part in the reliability analysis as observers. Before initiation of the study, the participants received a briefing about the radiological assessment of proximal femoral morphology and interpretation of $\mathrm{SI}$ in order to standardize the assessments. All radiographs were anonymous and presented to the observers in random order. The measurements were performed using a translucent ruler and a pencil. All radiologic assessments were performed in random order by each observer on two separate occasions, at least 4 weeks apart. Observers repeated their readings without knowledge of both their previous measurements and BMD. The order of the x-rays was randomized using a sequential random number generator to prevent possible recall. Determination of SI was made according to the principles presented in the original article by Singh et al. Observers assigned a Singh grading between 6 and 1 to each radiograph. Descriptions of $\mathrm{SI}$ are given in Table 1. CTI was calculated as the ratio of cortical thickness to bone diameter at a location $10 \mathrm{~cm}$ distal to the lesser trochanter (Figure 1). CCR was calculated as the ratio of the isthmus canal width divided by the calcar canal dimension (Figure 2)

\section{Cortical Thickness Index: (a-b)/a}

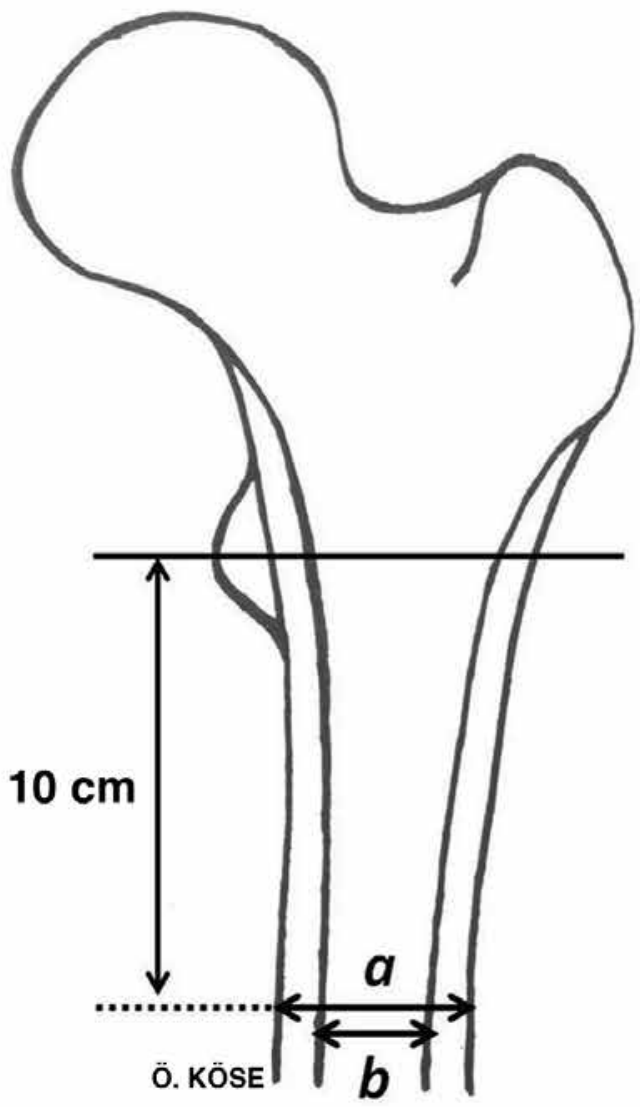

\section{Statistical Analysis}

In the first part of the statistical analysis we have evaluated the reliability of the measurement methods. For SI, kappa statistics were used to establish a relative level of agreement between observers for the two readings and between separate readings by the same observer. Interpretation of the data was performed according to Landis and Koch (14). An agreement is graded as slight (kappa=0-0.2), fair (kappa=0.21-0.40), moderate (kappa $=0.41-0.60)$, substantial (kappa $=0.61-0.80)$ and almost perfect (kappa=0.81-1). To test the reliability of radiographic indices, the degree of agreement between the observers was calculated by the interclass correlation coefficient (ICC) in 95\% confidence interval. Cicche provides commonly-cited cutoffs for qualitative ratings of agreement based on ICC values, with IRR being poor for ICC values less than 0.40, fair for values between 0.41 and 0.59, good for values between 0.60 and 0.74 , and excellent for values between 0.75 and 1.0. In the second part of the analysis, we have analyzed the correlation between each radiographic measurement method and $B M D, T$ score and $Z$ score. Correlation coefficient (Pearson $r$ ) was used to determine the relationship between the variables. The mean value of the radiographic measurements performed by two observers in two occasions was used as the resultant value for analysis in continuous variables. Finally ROC curve analysis was performed

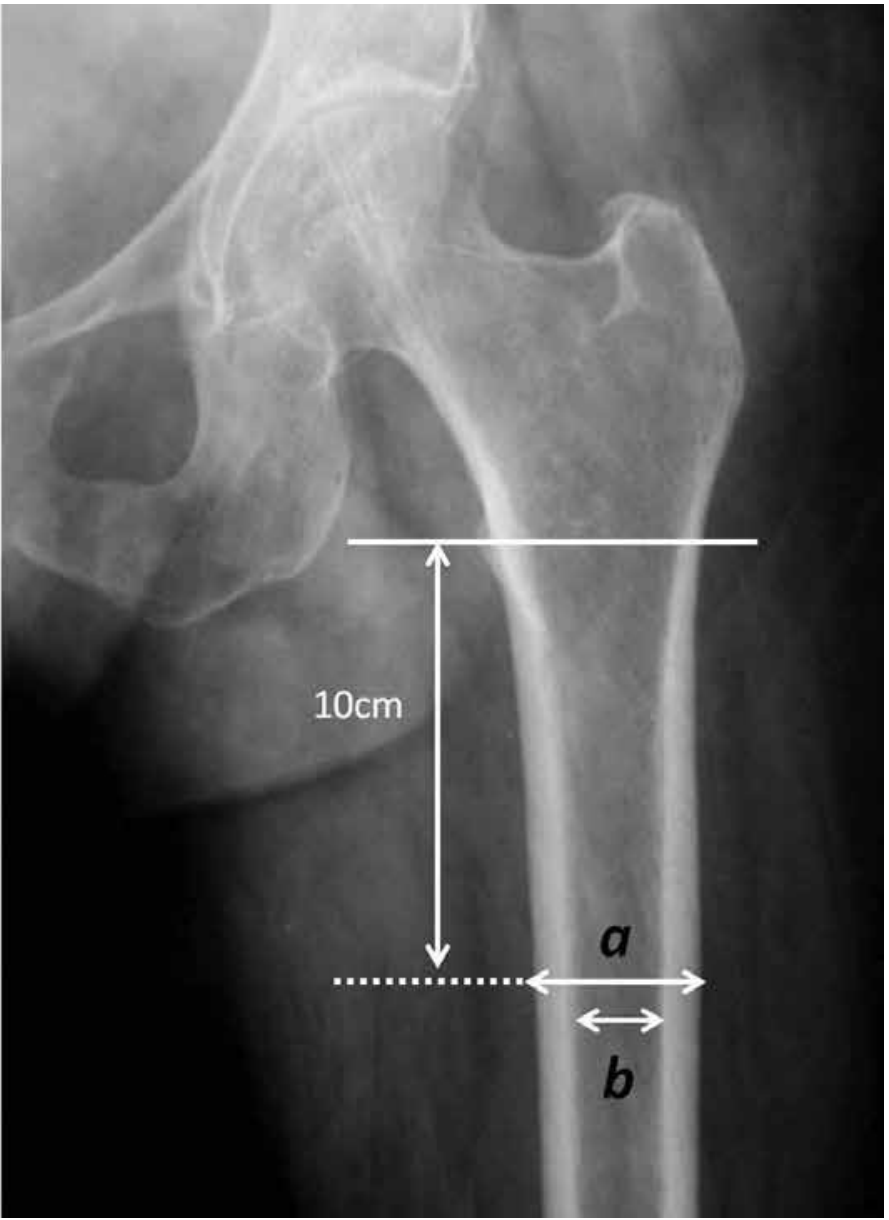

Figure 1. Cortical thickness index 
to determine the threshold values, sensitivity and specificity for each radiographic measurement method.

\section{Results}

There were 92 patients (all female) with a mean age of $72.0 \pm 8.9$ (range, 60-93). Of these patients, 35 had below $-2.5 \mathrm{~T}$ score and constitute the osteoporosis patients. Demographic and clinical characteristics of patients are presented in Table 2. Intra-observer reliability analysis of $\mathrm{SI}$ revealed kappa coefficient of 0.359 for observer $A$, and 0.224 for observer B (fair agreement for both observers). Interobserver reliability analysis of SI revealed kappa coefficient of 0.070 for observer $A$ and 0.051 for observer B (slight agreement for both observers). The intra-observer and interobserver reliability was good and excellent for CTI and CCR for both observers (Table 3). There was no correlation between $\mathrm{SI}$ interpretation of each observer on each occasion and DXA measurements (BMD, T score and Z score). On the other hand, there was significant correlation between $C T I$ and $C C R$ and DXA measurements (BMD, T score and Z score) (Table 4). All measured indices were significantly different $(p<0.05)$ between osteoporotic and non-osteoporotic patients (Table 5). CTI value less than 0.3 or CCR value less than 0.47 reflects the presence of osteoporosis with 100\% sensitivity and 98\% specificity (Table 6).

\section{Discussion}

In this study, relationship between radiographic measurements that specify the proximal femoral morphology and texture and BMD measurements were investigated. Furthermore reliability analysis of these measurements was tested. According to our findings, SI had very low (lower than acceptable limits) inter and intra-observer agreement between observers and between the separate assessments of the same observer. Moreover, these assessments did not correlate with the BMD values. On the other hand, both CTI and CCR showed good and excellent reliability, and each index correlated well with the real BMD values. CTI value less than 0.3 or CCR value less than 0.47 reflects the presence of osteoporosis with $100 \%$ sensitivity and $98 \%$ specificity.

Since SI has been published in 1970, several other authors studied the reliability and validity of this measurement method. There are controversial findings in relevant literature on both reliability and validity of $\mathrm{SI}$ in prediction of osteoporosis. In a study by Koot et al., 72 consecutive patients were assessed by six observers using Singh index, and only three
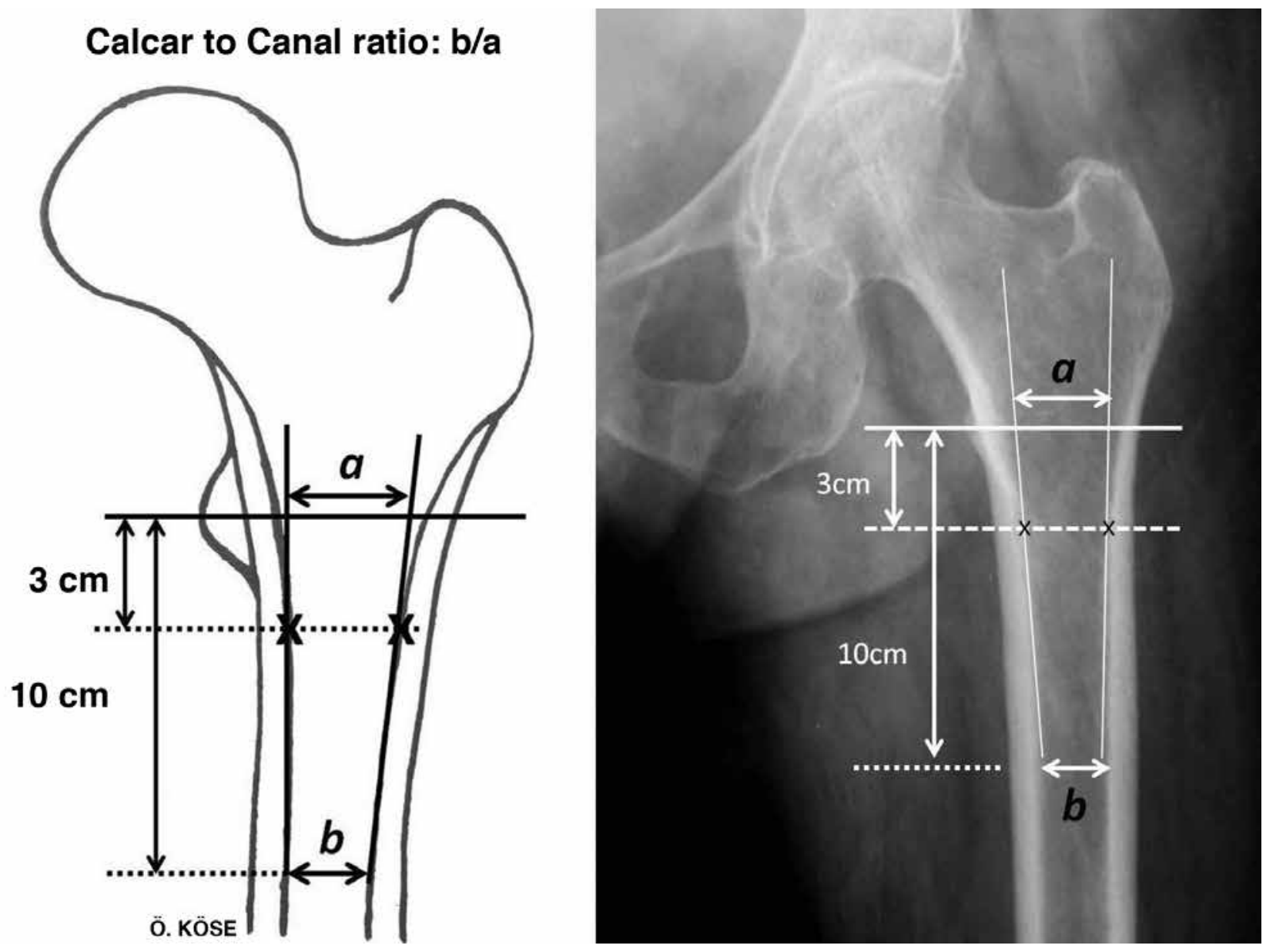

Figure 2. Calcar to canal ratio 


\begin{tabular}{|c|c|}
\hline Grade & Description \\
\hline 1 & Even the principal compressive trabeculae are markedly reduced in number and are no longer prominent. \\
\hline 2 & $\begin{array}{l}\text { Only the principal compressive trabeculae stand out prominently, the others have been more or less completely } \\
\text { resorbed. }\end{array}$ \\
\hline 3 & There is a break in the continuity of the principal tensile trabeculae. \\
\hline 4 & $\begin{array}{l}\text { Principal tensile trabeculae are markedly reduced in number but can still be traced from the lateral cortex to the upper } \\
\text { part of the femoral neck. }\end{array}$ \\
\hline 5 & $\begin{array}{l}\text { The structure of principal tensile and principal compressive trabeculae is accentuated. Ward's triangle appears } \\
\text { prominent. }\end{array}$ \\
\hline 6 & $\begin{array}{l}\text { All the normal trabecular groups are visible and the upper end of the femur seems completely occupied by cancellous } \\
\text { bone. }\end{array}$ \\
\hline
\end{tabular}

\section{Table 2. Demographic and clinical characteristics of patients}

\begin{tabular}{|l|l|}
\hline Variable & Value \\
\hline Number of patients & 92 \\
\hline Age (mean \pm SD years) & $72.0 \pm 8.9$ \\
\hline BMD (mean \pm SD) & $0.722 \pm 0.165$ \\
\hline T Score & $-1.71 \pm 1.46$ \\
\hline Z Score & $-1.79 \pm 1.23$ \\
\hline Body mass index (mean \pm SD kg/m²) & $31.6 \pm 7.7$ \\
\hline Duration of menopause (mean \pm SD years) & $24.7 \pm 9.3$ \\
\hline Presence of osteoporosis (Yes/No) & $35 / 57$ \\
\hline BMD: Bone mineral density & \\
\hline
\end{tabular}

Table 3. Inter and intra-observer reliability analysis of indices and Singh index used to assess the proximal femoral geometry.

\begin{tabular}{|c|c|c|c|c|}
\hline Variable & \multicolumn{2}{|c|}{ Reliability Analysis } & ICC $(95 \%$ CI) Kappa $(95 \%$ CI)* & Interpretation \\
\hline \multirow{6}{*}{ Calcar to Canal Ratio } & \multicolumn{3}{|c|}{ Intra-observer reliability } & \\
\hline & Observer A t1 & Observer A t2 & $0.920(0.879-0.947)$ & Excellent \\
\hline & Observer B t1 & Observer B t2 & $0.921(0.880-0.947)$ & Excellent \\
\hline & \multicolumn{3}{|c|}{ Inter-observer reliability } & \\
\hline & Observer A t1 & Observer B t1 & $0.846(0.768-0.898)$ & Excellent \\
\hline & Observer A t2 & Observer B t2 & $0.750(0.622-0.835)$ & Excellent \\
\hline \multirow{6}{*}{ Cortical Thickness Index } & \multicolumn{3}{|c|}{ Intra-observer reliability } & \\
\hline & Observer A t1 & Observer A t2 & $0.745(0.615-0.832)$ & Excellent \\
\hline & Observer B t1 & Observer B t2 & $0.936(0.903-0.958)$ & Excellent \\
\hline & \multicolumn{3}{|c|}{ Inter-observer reliability } & \\
\hline & Observer A t1 & Observer B t1 & $0.822(0.731-0.883)$ & Excellent \\
\hline & Observer A t2 & Observer B t2 & $0.624(0.431-0.751)$ & Good \\
\hline \multirow{6}{*}{ Singh Index } & \multicolumn{4}{|c|}{ Intra-observer reliability } \\
\hline & Observer A t1 & Observer A t2 & $0.359(0.213-0.504)^{*}$ & Fair \\
\hline & Observer B t1 & Observer B t2 & $0.224(0.092-0.355)^{*}$ & Fair \\
\hline & \multicolumn{4}{|c|}{ Inter-observer reliability } \\
\hline & Observer A t1 & Observer A t2 & $0.070(0.053-0.193)^{\star}$ & Slight \\
\hline & Observer B t1 & Observer B t2 & $0.051(0.050-0.156)^{*}$ & Slight \\
\hline
\end{tabular}


of 72 radiographs were given the same classification by all six observers. Moreover, they found no correlation between SI and BMD (14). Sah et al. studied whether there is a correlation between $\mathrm{SI}$ and $\mathrm{T}$ score in 32 postmenopausal women. Hip radiographs were rated by three observers to assign the Singh grade. Although they reported acceptable inter-rater reliability (kappa 0.88), SI was not significantly different between osteoporotic and non-osteoporotic patients, and no significant correlation was found between SI and T score (15). Im et al. investigated the association between SI and BMD in 140 Korean adults. They reported excellent inter-observer reliability of SI (ICC=0.85), however SI was not associated with BMD (16). Salamat et al. reported a large inter-observer variation (mean kappa 0.05) between three orthopedic surgeons, and could not determine any correlation the SI and BMD (17). In contrast to these findings, there are also studies which reported acceptable inter and intra-observer reliability, and significant correlation between SI ad BMD. Bes et al. investigated the reliability of $\mathrm{SI}$, and its relationship with real BMD values in patients with rheumatoid arthritis (18). They found substantial intra- and inter-observer agreements with a mean kappa of 0.71 (range, 0.69 to 0.72 ). Furthermore, they reported good correlation between $\mathrm{SI}$ and BMD and high sensitivity for the diagnosis of osteopenia at the proximal femur (91\%). D'Amelio et al. assessed the predictive value of SI to estimate the BMD and mechanical properties of bone (strength and elastic modulus). They suggested that $\mathrm{SI}$ is highly predictive both for BMD and mechanical properties (19). It is clear that, there is still no consensus on the use of SI regarding reliability and validity. Our findings were consistent with the previous reports that claimed $\mathrm{SI}$ is neither reliable nor valid, and we believe that SI should not be used for prediction of osteoporosis in clinical practice. SI is a semi-quantitative method and in order to assess the trabecular texture, standard and good quality radiographs are required. Moreover, $\mathrm{SI}$ is not an easy classification to memorize and it is subject to inter and intra-observer variation. SI should be refined to improve its objectivity.

Apart from Sl, other evaluation methods used to predict the quality of bone at proximal femur has been described such as CTI and CCR. These parameters were first intended to determine the type of femoral stem (cemented versus cementless) in patients undergoing hip arthroplasty (13). In our study, both CCR and CTI measurement methods were found to reliable. Inter-observer and intra-observer reliability analysis showed good and excellent agreement between observers. Furthermore, both CTI and CCR correlated with BMD. CTI and CCR are simple measurement methods which can be easily performed on direct hip radiographs and can

\section{Table 4. Correlation analysis of Singh index, Calcar to canal ratio and Cortical thickness index with DXA} measurements

\begin{tabular}{|l|l|l|l|l|l|l|l|}
\hline \multirow{2}{*}{ BMD } & Observer A t1 & Observer A t2 & Observer B t1 & Observer B t2 & Mean CCR & Mean CTI \\
\cline { 2 - 8 } & Pearson Correlation & 0.180 & -0.024 & -0.035 & 0.076 & -0.303 & 0.591 \\
\hline \multirow{2}{*}{ T Score } & Sig. (2-tailed) & 0.086 & 0.818 & 0.740 & 0.471 & $0.003^{*}$ & $0.0001^{*}$ \\
\cline { 2 - 8 } & Pearson Correlation & 0.156 & -0.065 & -0.057 & 0.058 & -0.327 & 0.588 \\
\hline \multirow{2}{*}{ Z Score } & Sig. (2-tailed) & 0.137 & 0.537 & 0.587 & 0.583 & $0.001^{*}$ & $0.0001^{*}$ \\
\cline { 2 - 8 } & Pearson Correlation & 0.165 & -0.043 & 0.050 & 0.155 & -0.208 & 0.475 \\
\cline { 2 - 8 } & Sig. (2-tailed) & 0.115 & 0.687 & 0.638 & 0.140 & $0.047^{*}$ & $0.0001^{*}$ \\
\hline
\end{tabular}

BMD: Bone mineral density, CCR: Calcar to canal ratio, CTI: Cortical thickness index, t1: First assessment, t2: Second assessment of the observers

Table 5. Comparison of Cortical thickness index and Calcar to canal ratio in osteoporotic and non-osteoporotic patients

\begin{tabular}{|l|l|l|l|l|}
\hline \multirow{2}{*}{ Mean CTI } & Osteoporosis & $\mathbf{n}$ & Mean \pm SD & p value \\
\hline \multirow{2}{*}{ Mean CCR } & No Osteoporosis & 57 & $0.51 \pm 0.07$ & 0.0001 \\
\cline { 2 - 5 } & Osteoporosis & 35 & $0.43 \pm 0.06$ & 0.0001 \\
\cline { 2 - 5 } & No Osteoporosis & 57 & $0.68 \pm 0.10$ & $0.74 \pm 0.08$ \\
\cline { 2 - 5 } & Osteoporosis & 35 & \\
\hline
\end{tabular}

Table 6. ROC analysis

\begin{tabular}{|l|l|l|l|l|}
\hline Variable & Area under curve (AUC) & Cut-off value & Sensitivity (\%) & Specificity (\%) \\
\hline CCR & 0.671 & 0.47 & 100 & 98 \\
\hline CTI & 0.185 & 0.30 & 100 & 98 \\
\hline CCR: Calcar to canal ratio, CTI: Cortical thickness index
\end{tabular}


predict the degree of osteoporosis correctly (13). Our results are consistent with several previous studies however threshold values were different in studies performed in different ethnic populations. Sah et al. reported that a CTI ratio less than 0.50 indicate osteoporosis in American population (15). Yun et al. reported that a CTI value less than 0.57 indicates osteoporosis in Korean population (20). On the other hand, we found the threshold value for $\mathrm{CTI}$ as 0.30. Similar discrepancies are also present for CCR. Yueng et al. reported a CCR ratio less than 0.57 indicate osteoporosis in Chinese population (21). However, we found a CCR ratio of 0.47 as threshold value for osteoporosis. Femoral geometry is subject to changes between different ethnic groups. These changes may result from congenital traits and also from nutritional habits and the geographical differences.

There are some strengths and limitations of this study. Relatively small number of patients is included in this study and all patients were female. Therefore, we cannot generalize our findings to both genders. However, our study design is sufficient for explaining our hypothesis. Furthermore, not only validity but also the reliability of all measures was performed.

In conclusion, proximal femoral morphology can provide valuable information about the degree of osteoporosis in postmenopausal women. $\mathrm{SI}$ is an unreliable and invalid method to assess the degree of osteoporosis, however CCR and CTI are objective indices that can used in clinical practice, and may provide information about the presence of osteoporosis. However, ethnic differences should be kept in mind during decision making.

\section{References}

1. Wade SW, Strader C, Fitzpatrick LA, Anthony MS, O'Malley CD. Estimating prevalence of osteoporosis: examples from industrialized countries. Arch Osteoporos 2014;9:182.

2. Akan K, Cift H, Ozkan K, Eceviz E, Tasyikan L, Eren A. Effect of osteoporosis on clinical outcomes in intertrochanteric hip fractures treated with a proximal femoral nail. J Int Med Res 2011;39:857-65.

3. Cornell CN: Internal fracture fixation in patients with osteoporosis. J Am Acad Orthop Surg 2003;11:109-19.

4. Schipper IB, Steyerberg EW, Castelein RM, van der Heijden FH, den Hoed PT, Kerver AJ, et al. Treatment of unstable trochanteric fractures. Randomised comparison of the gamma nail and the proximal femoral nail. J Bone Joint Surg Br 2004;86:86-94.
5. Kim WY, Han $\mathrm{CH}$, Park JI, Kim JY. Failure of intertrochanteric fracture fixation with a dynamic hip screw in relation to pre-operative fracture stability and osteoporosis. Int Orthop 2001;25:360-2.

6. Kim SS, Lee MJ, Kim HJ, Kang JM. Comparison of femoral morphology and bone mineral density between femoral neck fractures and trochanteric fractures in $65+$ females. Hip Pelvis 2012;24:102-8.

7. Maeda Y, Sugano N, Saito M, Yonenobu K. Comparison of femoral morphology and bone mineral density between femoral neck fractures and trochanteric fractures. Clin Orthop Relat Res 2011;469:884-9.

8. Kanis JA, Gluer CC. An update on the diagnosis and assessment of osteoporosis with densitometry. Committee of Scientific Advisors, International Osteoporosis Foundation. Osteoporos Int 2000;11:192-202.

9. Pramudito JT, Soegijoko S, Mengko TR, Muchtadi FI, Wachjudi RG. Trabecular Pattern Analysis of Proximal Femure Radiographs for Osteoporosis Detection, Journal of Biomedical \& Pharmaceutical Engineering 2007;1:45-51.

10. Singh $M$, Nagrath $A R$ and Maini PS. Change in trabecular pattern of the upper end of the femur as an index to osteoporosis. J Bone Joint Surg Am 1970;52:457-67.

11. Dorr LD. Total hip replacement using APR system. Tech Orthop 1986;1:22-34.

12. Dorr LD, Gaugere MC, Mackel AM, Gruen TA, Bognar B, Malluche $\mathrm{HH}$. Structural and cellular assessment of bone quality of proximal femur. Bone 1993;14:231-42.

13. Rosson JW, Surowiak J, Schatzker J, Hearn T. Radiographic appearance and structural properties of proximal femoral bone in total hip arthroplasty patients J Arthroplasty 1996;11:180-3.

14. Koot VC, Kesselaer SM, Clevers GJ, de Hooge P, Weits T, van der Werken $C$. Evaluation of the Singh index for measuring osteoporosis. J Bone Joint Surg Br 1996;78:831-4.

15. Sah AP, Thornhill TS, Leboff MS, Glowacki J. Correlation of plain radiographic indices of the hip with quantitative bone mineral density Osteoporos Int. 2007;18:1119-1126.

16. Im GI, Park PG, Moon SW. The relationship between radiological parameters from plain hip radiographs and bone mineral density in a Korean population. J Bone Miner Metab 2012;30:504-8.

17. Salamat MR, Rostampour N, Zofaghari SJ, Hoseyni-Panah H,Javdan M. Comparison of Singh index accuracy and dual energy X-ray absorptiometry bone mineral density measurement for evaluating osteoporosis. Iran J Radiat Res 2010;8:123-8.

18. Bes C, Güven M, Akman B, Atay EF, Ceviz E, Soy M. Can bone quality be predicted accurately by Singh index in patients with rheumatoid arthritis? Clin Rheumatol 2012;31:85-9.

19. D’Amelio P, Rossi P, Isaia G, Lollino N, Castoldi F, Girardo M, et al. Bone mineral density and Singh index predict bone mechanical properties of human femur. Connect Tissue Res 2008;49:99-104.

20. Yun HH, Yi JW, Lim DS, Park DS, Oh RS. Reliability of the Radiologic Measurement Methods for Assessment of Osteoporosis Using the Digital Hip Radiograph. J Korean Hip Soc 2011;23:142-50.

21. Yeung Y, Chiu KY, Yau WP, Tang WM, Cheung WY, Ng TP. Assessment ofthe proximal femoral morphology using plain radiograph-can it predict the bone quality? J Arthroplasty 2006;21:508-13. 